\title{
Finger prick blood testing in Leber hereditary optic neuropathy
}

David Mackey, Steve Nasioulas, Susan Forrest

\begin{abstract}
Individuals from 33 unrelated Australian families with optic atrophy were screened for 10 different single base alterations in mitochondrial DNA (mtDNA) associated with Leber hereditary optic neuropathy (LHON) using direct polymerase chain reaction amplification of blood spots collected on Guthrie cards. This method using blood spots allows easily accessible screening for LHON mtDNA mutations with minimal biohazard risk and reduced expense in the storage and transport of specimens.
\end{abstract}

(Brf Ophthalmol 1993; 77: 311-312)

Leber hereditary optic neuropathy (LHON) commonly presents as a bilateral sequential visual loss which may be associated with

\section{Table 1 mtDNA base changes associated with LHON}

$\mathrm{mt}$ base restriction enzyme sites altered

gene mutation

$\star 3460 \mathrm{G}>\mathrm{A}$ loss of $\mathrm{HgaI}$, AcyI, AhalI, BbilI, Hinll ${ }^{7}$

ND1 A52T

$4160 \mathrm{~T}>\mathrm{C}$ loss of AluI (with mismatch primer) ${ }^{6}$

ND1 L285P

4216 $\mathrm{T}>\mathrm{C}$ creation of NlaIII, $\mathrm{NspHI}^{9}$

4917 A $>$ G creation of MaeI, $\mathrm{RmaI}^{9}$

ND2 D150N

$5244 \mathrm{G}>\mathrm{A}$ loss of HpaII, HapII ${ }^{10}$

ND2 G259S

$7444 \mathrm{G}>\mathrm{A}$ loss of $\mathrm{Xba}^{1011}$

Cox ter K

$\star 11778 \mathrm{G}>\mathrm{A}$ loss of SfaNI, creation of MaeIII ${ }^{12-14}$

ND4 R340H

$13708 \mathrm{G}>\mathrm{A}$ loss of BstNI, Fnu4HI, ApyI, EcoRII, MvaI

ND5 A458T

$15257 \mathrm{G}>\mathrm{A}$ loss of $\mathrm{AccI}^{10}$

CytB D171N

$15812 \mathrm{G}>\mathrm{A}$ loss of Rsa, Csp6 ${ }^{10}$

CytB V356M

^There is strong evidence that these mutations are causative.

Victoria, 3052, Australia.

Accepted for publication

2 February 1993

Table 2 PCR primers, products, enzymes, and fragments used in this study

\begin{tabular}{|c|c|c|c|c|c|}
\hline Site gene & 5' Primer & 3'Primer & Frag & Enzyme & $\begin{array}{l}\text { PCR fragments } \\
\text { size }\end{array}$ \\
\hline $\begin{array}{l}3460 \\
\text { ND1 } \\
4160 \\
\text { ND2 } \\
4216 \\
\text { ND2 } \\
4917 \\
\text { ND2 } \\
5244 \\
\text { ND2 } \\
7444 \\
\text { Cox } \\
11778 \\
\text { ND4 } \\
13708 \\
\text { ND5 } \\
15257 \\
\text { CytB1 } \\
15812 \\
\text { CytB1 }\end{array}$ & $\begin{array}{l}3275-3295 \\
(21-\mathrm{mer}) \\
4137-4159 \\
(4158 \mathrm{G}, 23-\mathrm{mer}) \\
4137-4159 \\
(4158 \mathrm{G}, 23-\mathrm{mer}) \\
4680-4700 \\
(21-\mathrm{mer}) \\
5195-5212 \\
(21-\mathrm{mer}) \\
7353-7373 \\
(21-\mathrm{mer}) \\
11660-11683 \\
(24-\mathrm{mer}) \\
13567-13587 \\
(21-\mathrm{mer}) \\
15081-15101 \\
(21-\mathrm{mer}) \\
15749-15769 \\
(21-\mathrm{mer})\end{array}$ & $\begin{array}{l}3553-3573 \\
(21-\mathrm{mer}) \\
4281-4301 \\
(21-\mathrm{mer}) \\
4281-4301 \\
(21-\mathrm{mer}) \\
4980-5000 \\
(21-\mathrm{mer}) \\
5526-5546 \\
(21-\mathrm{mer}) \\
7650-7670 \\
(21-\mathrm{mer}) \\
11896-11919 \\
(24-\mathrm{mer}) \\
13869-13889 \\
(21-\mathrm{mer}) \\
15290-15310 \\
(21-\mathrm{mer}) \\
15919-15939 \\
(21-\mathrm{mer})\end{array}$ & $\begin{array}{l}299 \\
165 \\
165 \\
321 \\
352 \\
318 \\
260 \\
323 \\
230 \\
191\end{array}$ & $\begin{array}{l}\text { AcyI^ } \\
\text { AluI }^{\star} \\
\text { NspHI }^{\star} \\
\text { MaeI }^{\star} \\
\text { HpaII } \dagger \\
\text { XbaI } \dagger \\
\text { SfaNI } \dagger \\
\text { MaeIII } \\
\text { Fnu4HI } \dagger \\
\text { Acc I } \dagger \\
\text { Rsa } †\end{array}$ & $\begin{array}{l}18 \underline{4+1} 15 \\
2 \underline{2+1} 43 \\
8 \underline{3+82} \\
106+90+3 \underline{9+86} \\
4 \underline{8+304} \\
23 \underline{0+88} \\
13 \underline{0+1} 30 \\
11 \underline{5+1} 31+14 \\
13 \underline{\underline{9}+1} 84 \\
17 \underline{5+55} \\
6 \underline{5+126}\end{array}$ \\
\hline
\end{tabular}

5 ' Primers are complementary to the $\mathrm{H}$ strand, 3 ' primers are complementary to the $\mathrm{L}$ strand of mtDNA. Numbering is as in the Cambridge sequence. LHON site is underlined.

$\star$ Boehringer Mannheim, Indianapolis, IN, USA

†New England Biolab, Beverly, MA, USA.

characteristic optic disc swelling and peripapillary telangiectasia. ${ }^{12}$ Diagnosis of $\mathrm{LHON}$ is difficult if the affected individual falls outside the classic presentation of a young adult male with a family history of similar visual loss. Fifty per cent of patients presenting with LHON are not men between 18 and 30 years. ${ }^{2}$ DNA testing for the various single base alterations in mitochondrial DNA (mtDNA) that have been associated with LHON (Table 1) is helpful in the diagnosis even though the aetiological significance of these alterations is not yet clearly defined. Recently, direct polymerase chain reaction (PCR) amplification from Guthrie cards has been used in testing for phenylketonuria ${ }^{3}$ and cystic fibrosis. ${ }^{4}$ We used direct PCR amplification of blood from Guthrie cards to detect the described mtDNA base changes of LHON.

\section{Method}

Informed consent was obtained from patients or, where relevant, parents. Approximately $0.25 \mathrm{ml}$ of blood was placed on a Guthrie card and allowed to air dry. With young children Guthrie cards taken at birth were obtained from the neonatal screening laboratories. A $2.5 \mathrm{~mm}$ (approximately $3 \mu \mathrm{l}$ ) disc of dried blood was punched from the card for each PCR fragment amplification, using sterile laboratory methods. Each blood spot was soaked in a solution of $10 \mu \mathrm{l}$ 1\% Triton X-100 (Sigma, St Louis MO), PCR buffer [20 $\mu$ l $5 \times$ PCR buffer (Perkin Elmer Cetus, Norwalk, CT)] and distilled water to a final total of $100 \mu$ l (including the volume for dNTPs, primers, and enzymes) at $37^{\circ} \mathrm{C}$ for $1-24$ hours in a $1.5 \mathrm{ml}$ microcentrifuge tube. The eluted Guthrie spot was then boiled for 5 minutes and the appropriate pair of primers ${ }^{5} 1 \mu \mathrm{l}$ of each, $10 \mu \mathrm{l} 2 \mathrm{mmol} \mathrm{dNTPs}$, and Taq polymerase $1 \mu \mathrm{l}$ taq (PEC) were added. A PCR was run at $94^{\circ} \mathrm{C}$ for 90 seconds, $65^{\circ} \mathrm{C}$ for 150 seconds, and $72^{\circ} \mathrm{C}$ for 80 seconds for 25-35 cycles. After amplification, $16 \mu \mathrm{l}$ were then digested with the appropriate enzyme (Table 1). The resultant digest was run alongside the undigested PCR product on a $3 \%$ gel and the fragments compared under ultraviolet light (Table 2).

\section{Results}

More than 100 patients in 33 separate families have been studied by this method and the mutations confirmed by subsequent sequencing of extracted DNA. All but one of the DNA alterations of interest could be detected by restriction enzyme cleavage because they alter recognition sites of one or more enzymes (Table 2). The exception was the $4160 \mathrm{~T}$ to $\mathrm{C}$ mutation which does not alter any known restriction site. 
Table 3 Sequences around the $4160 \mathrm{mtDNA}$

\begin{tabular}{lrrr}
\hline & 4 & 4 & \\
& 1 & 1 & \\
& 5 & 6 & \\
Normal & 6 & 0 & \\
LHON(QId) & CAACT & \\
Mismatched primer & CAACC & \\
Sequence in normal PCR & N-CAGG & \\
Sequence in LHON(QId) PCR & N-CAGCT & AluI site \\
\hline
\end{tabular}

We created an AluI site in DNA of normal individuals by using a mismatched 23 base primer altering an $A$ to $G$ at position 4158 (Table 3). Loss of this AluI site suggests the presence of the $4160 \mathrm{~T}$ to $\mathrm{C}$ mutation. (The primer was designed to avoid the additional mtDNA 4136 base change found in two patients. ${ }^{6}$ )

The resultant fragment sizes are reported in Table 2. With SfaNI incomplete digestion was occasionally seen although this was easily checked as real heteroplasmy or as 'pseudoheteroplasmy' by concurrent use of MaeIII. ${ }^{12} 13$

Finally, to test if DNA from old cards could be successfully amplified we processed seven cards from children with the 11778 mutation that had been stored from 2 to 9 years in neonatal screening laboratories. The cards were soaked for up to 2 days before amplification. Fresh blood samples from the same patients all showed $100 \%$ mutant DNA. However the cards taken at birth showed apparent heteroplasmy in six of seven patients.

\section{Discussion}

PCR of Guthrie cards can be used to confirm the diagnosis of LHON in patients presenting with optic neuropathy. This is particularly important in atypical cases suspected of being LHON, multiple sclerosis, post-traumatic, or toxic nutritional amblyopia. The correct diagnosis allows adequate and correct genetic counselling.

This Guthrie card method could also be used to PCR amplify DNA for sequencing ${ }^{5}$ or GC clamped denaturing gradient electrophoresis (DGGE) methods of detecting DNA mutations. The apparent heteroplasmy may be due to cross contamination from adjacent cards during storage, or heteroplasmy may be present in the blood at birth and the normal mitochondrial genomes may disappear in time. This approach is useful in screening patients for further research. It also simplifies the technique for screening large numbers of people to establish the prevalence of these base changes in the general population.

We thank David Danks, Michaela Balnaves, and Henrik Dahl for advice on laboratory techniques; Evelyn Robertson and Ivan Francis for providing stored neonatal blood samples; Neil Howell and David McCullough for providing some of the primers used.

David Mackey was in receipt of a clinical research fellowship from the Royal Children's Hospital, Melbourne.

1 Nikoskelainen EK, Hoyt WF, Nummelin KU. Ophthalmoscopic findings in Leber's hereditary optic neuropathy. II. The fundus findings in affected family members. Arch Ophthalmol 1983; 101: 1059-68.

2 Mackey DA, Buttery RG. Leber hereditary optic neuropathy in Australia. Aust NZ F Ophthalmol 1992; 20: 177-84.

3 Schwartz EI, Khalchitsky SE, Eisensmith RC, Woo SLC. Polymerase chain reaction amplification from dried blood spots on Guthrie cards. Lancet 1990; 336: 639-40.

4 Nelson PV, Carey WF, Morris CP. Gene amplification directly from Guthrie blood spots. Lancet 1990; 336: 1451-2.

5 Howell N, McCullough DA. An example of Leber hereditary optic neuropathy not involving a mutation in the mito chondrial ND4 gene. Am F Hum Genet 1990; 47: 629-34.

6 Howell N, Kubacka I, Xu M, McCullough DA. Leber hereditary optic neuropathy: involvement of the mitochondrial NDl gene and evidence for an intragenic suppressor mutation. Am f Hum Genet 1991; 48: 935-42.

7 Howell N, Bindoff LA, McCullough DA, Kubacka I, Pouton J, Mackey D, et al. Leber hereditary optic neuropathy: identification of the same mitochondrial NDl mutation in six pedigrees. Am f Hum Genet 1991; 49: 939-50.

8 Huoponen K, Vilkki J, Aula P, Nikoskelainen EK, Savontaus Huponen K, Vilkki J, Aula P, Nikoskelainen EK, Savontaus
ML. A new mtDNA mutation associated with Leber ML. A new mtDNA mutation associated with Leber 48: 1147-53.

9 Johns DR, Berman J. Alternative, simultaneous complex 1 mitochondrial DNA mutations in Leber's hereditary optic neuropathy. Biochem Biophys Res Commun 1991; 174: 1324 30.

10 Brown MD, Voljavec AS, Lott MT, Torroni A, Yang C-C, Wallace DC. Mitochondrial DNA complex I and III mutations associated with Leber's hereditary optic neuropathy. Genetics 1992; 130: 163-73.

11 Brown MD, Yang C-C, Trounce I, Torroni A, Lott MT, Wallace DC. A mitochondrial DNA variant, identified in Leber hereditary optic neuropathy patients, which extends the amino acid sequence of cytochrome $c$ oxidase subunit I. Am $\mathcal{F}$ Hum Genet 1992; 51: 378-85.

12 Wallace DC, Singh G, Lott MT, Hodge JA, Schurr TG, Lezza AM, et al. Mitochondrial DNA mutation associated with Leber's hereditary optic neuropathy. Science 1988; 242: 1427-30.

13 Stone EM, Coppinger JM, Kardon RH, Donelson JE. Mae III positively detects the mitochondrial mutation associated with type I Leber's hereditary optic neuropathy. Arch Ophthalmol 1990; 108: 1417-20.

14 Johns DR. Improved molecular-genetic diagnosis of Leber's hereditary optic neuropathy [Letter]. $N$ Engl F Med 1990; 323: 1488-9. 